\title{
Comparative Study of Reinforced Concrete Frame Building and RC-Steel Composite Frame Building
}

\author{
Sourabh M. Jadhav ${ }^{1}$, J. P. Patankar ${ }^{2}$ \\ ${ }^{1}$ First Author Affiliation \& Address \\ ${ }^{2}$ Second Author Affiliation \& Address Font size 11 \\ ${ }^{3}$ Example: Professor, Dept. of xyz Engineering, xyz college, state, country
}

\begin{abstract}
Steel industry is growing in almost all parts of the world. The use of steel structure in construction industry is less in India as compared to USA, EU and other developed countries. As well cities in India are amongs high densely inhabitants per square $\mathbf{k m}$. which restricts horizontal expansion therefore vertical growth of building becomes predominant. Concrete structures are massive and bestow more seismic weight while steel structure take more ductility and deflection. Composite construction consolidates the better properties of steel and concrete.

In this study the static analysis under the provision of IS1893:2002 is carried out for three dimensional models RCC frame structure and RC-steel composite frame structure with the help of ETAB software. Comparative study of RCC frame structure and $\mathrm{RC}$-steel composite frame structure for $\mathbf{G + 9}$ is included.
\end{abstract}

Subject headings: Composite structures, steel structure framed structure, seismic design, ETABS v18

\section{INTRODUCTION}

In the past, for the construction, the choice was normally between a concrete structure and a masonary structure. Failure of many masonary buildings and multistoried RCC buildings due to earthquake have necessitate structural engineers to look for the different method of construction. Due to significant potential in improving the overall performance through rather modest changes in construction technology, use of composite frame structure is of particular intrest. There is great potential for increasing the volume of steel in construction. Especially the current development need in India. Use of steel, reinforced concrete, and composite steel concrete members which are functioning together such composite systems make use of each type of member in most efficient manner to maximize the structural and economical benefit.

\section{ELEMENTS OF COMPOSITE STRUCTURE}

\subsection{Shear connector}

Mechanical shear connectors are required at the steelconcrete interface. These connectors are designed to (a) transmit longitudinal shear along the interface and (b) prevent separation of steel beam and concrete slab at the interface. There are three types of shear connectors as,
(a) Rigid type
(b) Bond or anchorage type
(c) Flexible type

\section{2 composite deck slab}

Composite deck slab consist of composite column(encased hot rolled I section), steel beam, steel jacketing.

\section{3 composite beam}

The steel beams are connected to the concrete slab in such a way that the two act as one unit, the beam is called as composite beam. Composite beams are similar to concrete $\mathrm{T}$ beams where the flange of the T-beam is made of concrete slab and the web of the T-beam is made of the steel section.

\subsection{Composite column}

It is a compression member consisting either concrete encased hot rolled steel section embedded in concrete. At present there is no Indian standard code covering the design of composite column. The design method largely follows Euro code 4, which provides latest research on composite construction. IS 11384-1985 does not make any specific provisions to composite columns.

\section{METHODOLOGY}

RCC and steel-concrete frame models are analyzed. Seismic analysis of both RCC frame structure and composite frame structure are carried out using software tool ETAB v18. Different parameters such as shear force, storey stiffness, storey displacement, storey drift are discussed

\subsection{Structural details}

A typical plan of building is selected for comparative study of RCC and RC-steel composite having plan dimensions $25 \mathrm{~m} \times 16 \mathrm{~m}$ as shown in figure.,

3-D model is being prepared for the frame analysis of building in ETABS. Following basic parameters are used for analysis and design of structures.

\subsubsection{Material properties}

\begin{tabular}{|l|l|}
\hline Unit weight of masonary & $19 \mathrm{kN} / \mathrm{m}^{3}$ \\
\hline Unit weight of RCC & $25 \mathrm{kN} / \mathrm{m}^{3}$ \\
\hline Grade of concrete & $\mathrm{M} 30$ \\
\hline Grade of reinforcing steel & $\mathrm{HYSD} 500$ \\
\hline Grade of structural steel & $\mathrm{Fe} 250$ \\
\hline Modulus of elasticity for RCC & $25 \mathrm{kN} / \mathrm{m}^{2}$ \\
\hline Modulus of elasticity for steel & $210 \mathrm{kN} / \mathrm{m}^{2}$ \\
\hline Dead load & $\begin{array}{l}\text { Self weight of structural } \\
\text { elements }\end{array}$ \\
\hline Live load & $3 \mathrm{kN} / \mathrm{m}^{2}$ \\
\hline Floor finish load & $1 \mathrm{kN} / \mathrm{m}^{2}$ \\
\hline
\end{tabular}




\subsubsection{Earthquake parameters}

\begin{tabular}{|l|l|}
\hline Location & Pune, MH \\
\hline Seismic zone & III \\
\hline Soil type & Medium type II \\
\hline Importance factor & 1 \\
\hline Time period & Program calculated \\
\hline Earthquake load in & X \& Y direction \\
\hline Type of diaphragm & Rigid \\
\hline
\end{tabular}

\subsubsection{Model configuration}

The methodology adopted for achieving the above-mentioned objectives is as follows:

Model M1- Modelling of regular G+9 R.C.C building Model M2 - Modelling of G+9 building with composite steel beam and RCC column

Model M3 - Modelling of G+9 building with composite column(encased I section) and RCC beam

Model M4 - Modelling of G+9 building with composite steel beam and composite column.

Table -1: Description of model

\begin{tabular}{|l|l|}
\hline Number of bays in X direction & 5 \\
\hline Number of bays in Y direction & 4 \\
\hline Width of bays in X direction & $5 \mathrm{~m}$ \\
\hline Width of bays in Y direction & $4 \mathrm{~m}$ \\
\hline Height of typical storey & $3 \mathrm{~m}$ \\
\hline Height of bottom storey & $3.5 \mathrm{~m}$ \\
\hline Slab thickness & $120 \mathrm{~mm}$ \\
\hline Shear wall thickness & $250 \mathrm{~mm}$ \\
\hline
\end{tabular}

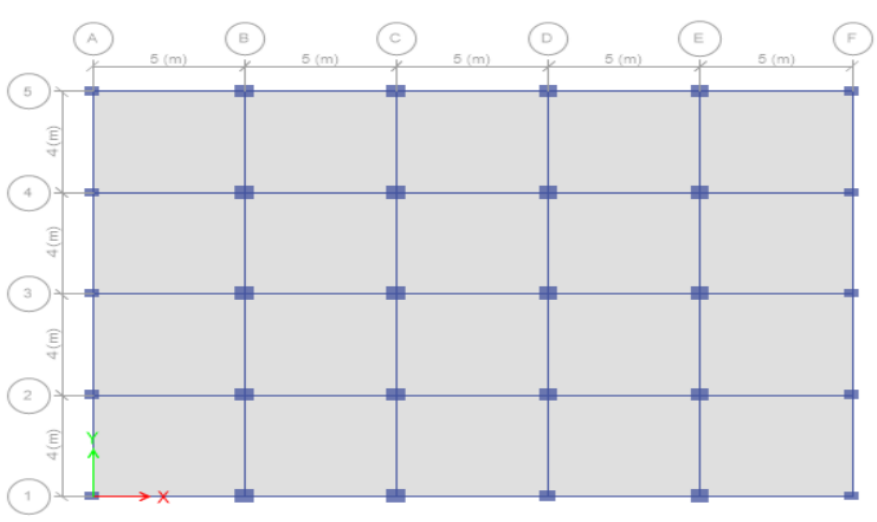

Fig 1: Plan

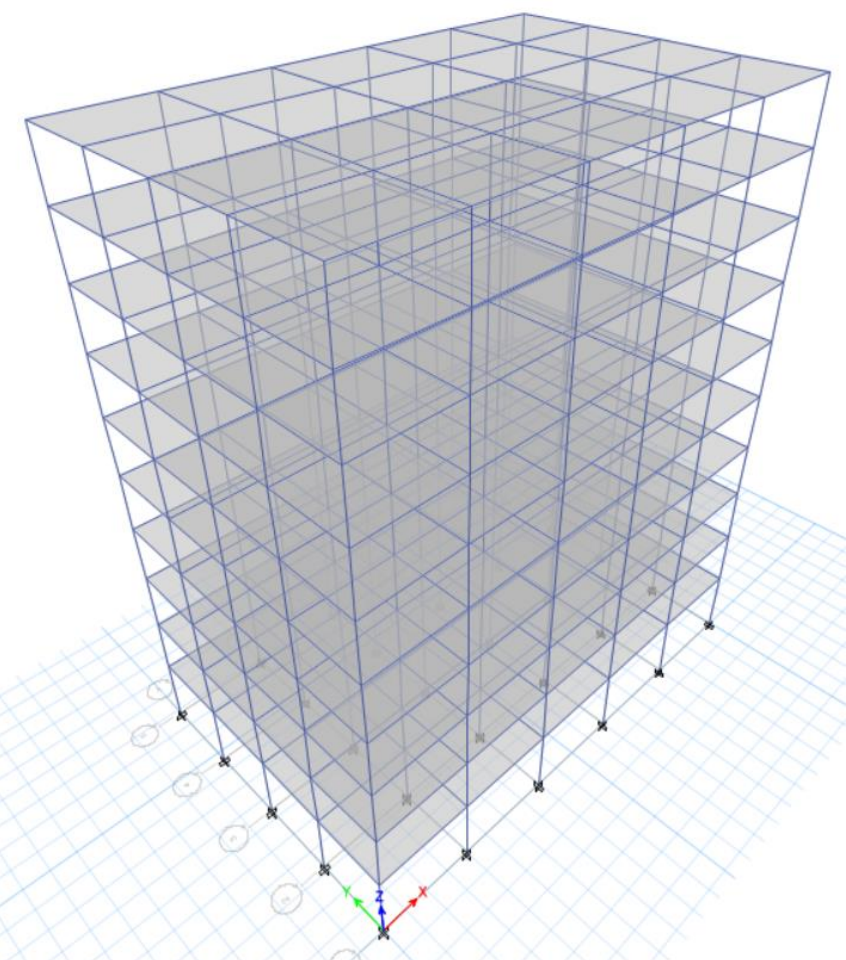

Fig. 3D view

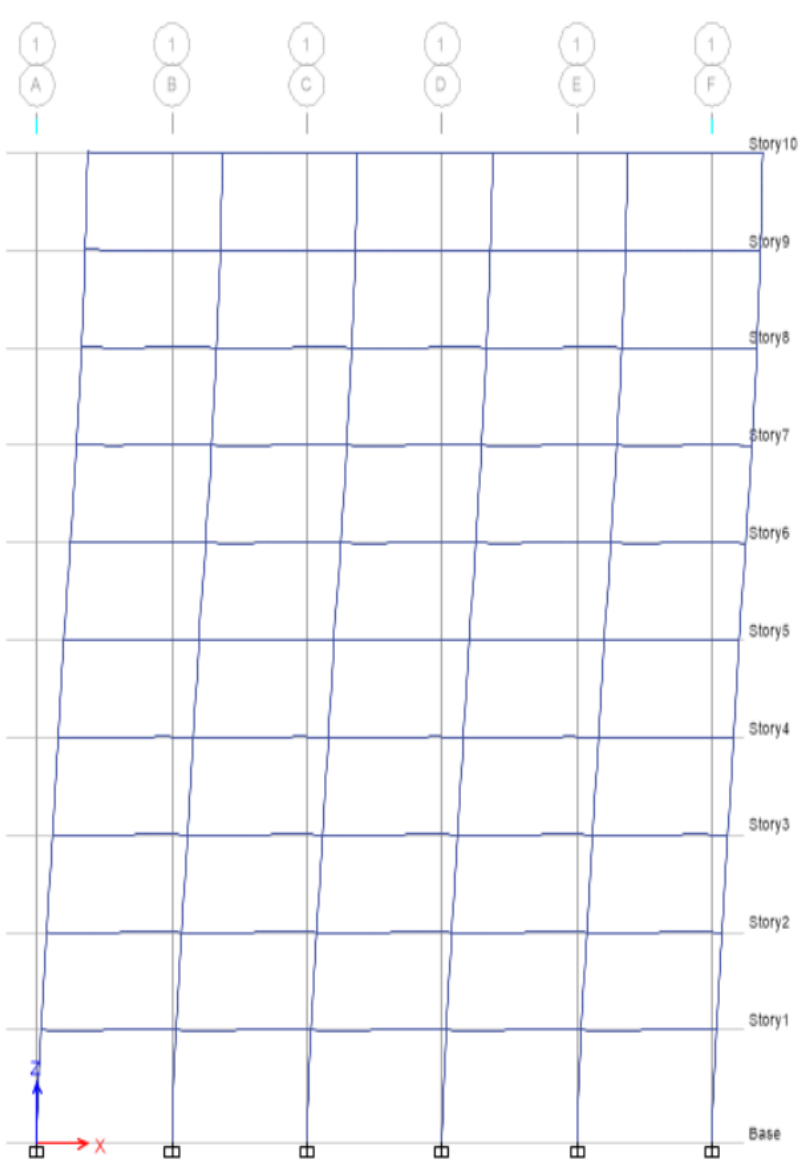

Fig 4. Deformed shape of G+9 storey building 


\section{Due to lateral loading}

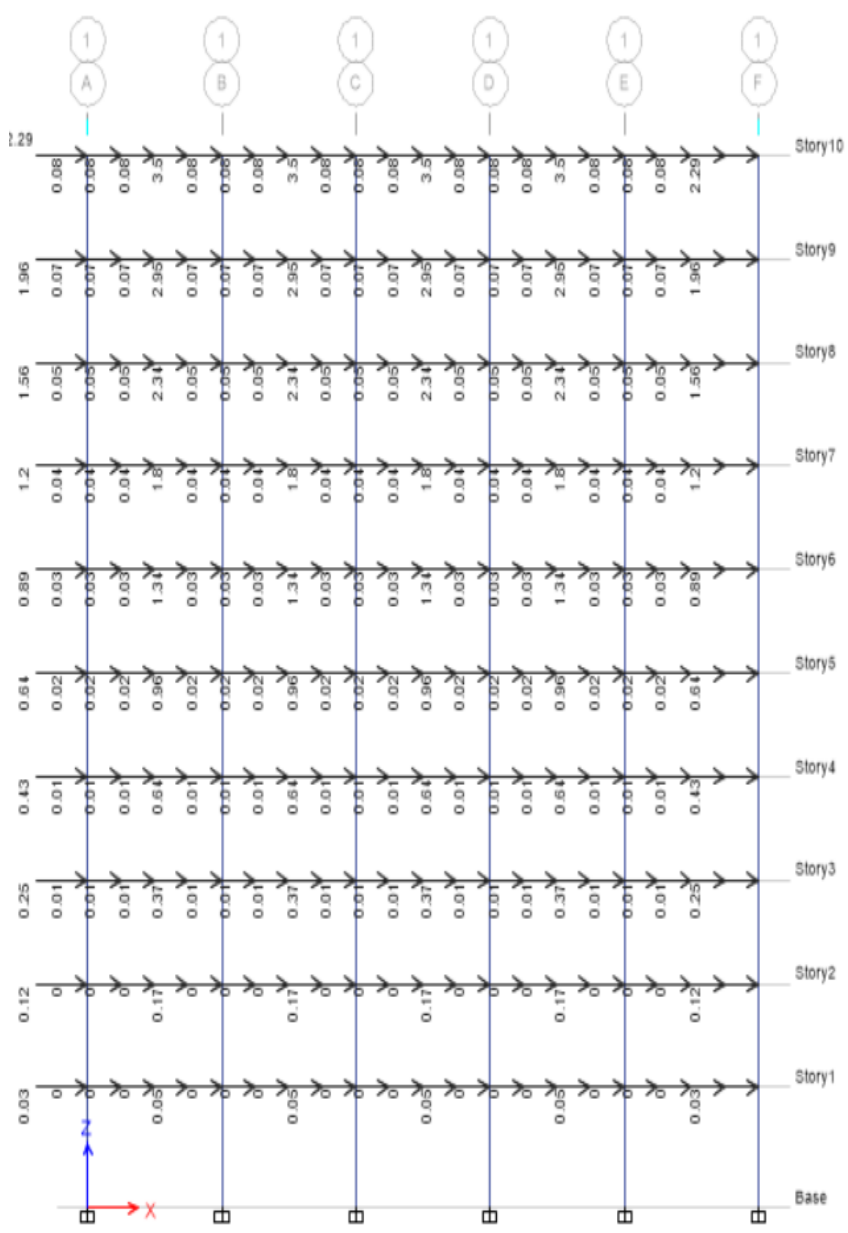

Fig 5. Joint load due to lateral loading.

$$
\text { 4. RESULTS }
$$

\subsection{Max. Storey displacement}

4.1.1 Max Storey Displacement due to earthquake in Xdirection

\begin{tabular}{|l|l|l|l|l|}
\multicolumn{7}{|c|}{ Table no. 1 } \\
\hline Storey & M1 & M2 & M3 & M4 \\
\hline 0 & 0 & 0 & 0 & 0 \\
\hline 1 & 1.094 & 1.005 & 1.056 & 0.972 \\
\hline 2 & 2.632 & 2.47 & 2.575 & 2.421 \\
\hline 3 & 4.282 & 4.063 & 4.218 & 4.01 \\
\hline 4 & 5.923 & 5.655 & 5.857 & 5.604 \\
\hline 5 & 7.497 & 7.184 & 7.43 & 7.136 \\
\hline 6 & 8.954 & 8.598 & 8.886 & 8.553 \\
\hline 7 & 10.245 & 9.847 & 10.173 & 9.803 \\
\hline 8 & 11.313 & 10.879 & 11.238 & 10.835 \\
\hline 9 & 12.106 & 11.645 & 12.028 & 11.603 \\
\hline 10 & 12.609 & 12.136 & 12.533 & 12.099 \\
\hline
\end{tabular}

MAXIMUM STOREY DISPLACEMENT DUE TO

$$
\text { EARTHQUAKE IN X-DIRECTION }
$$

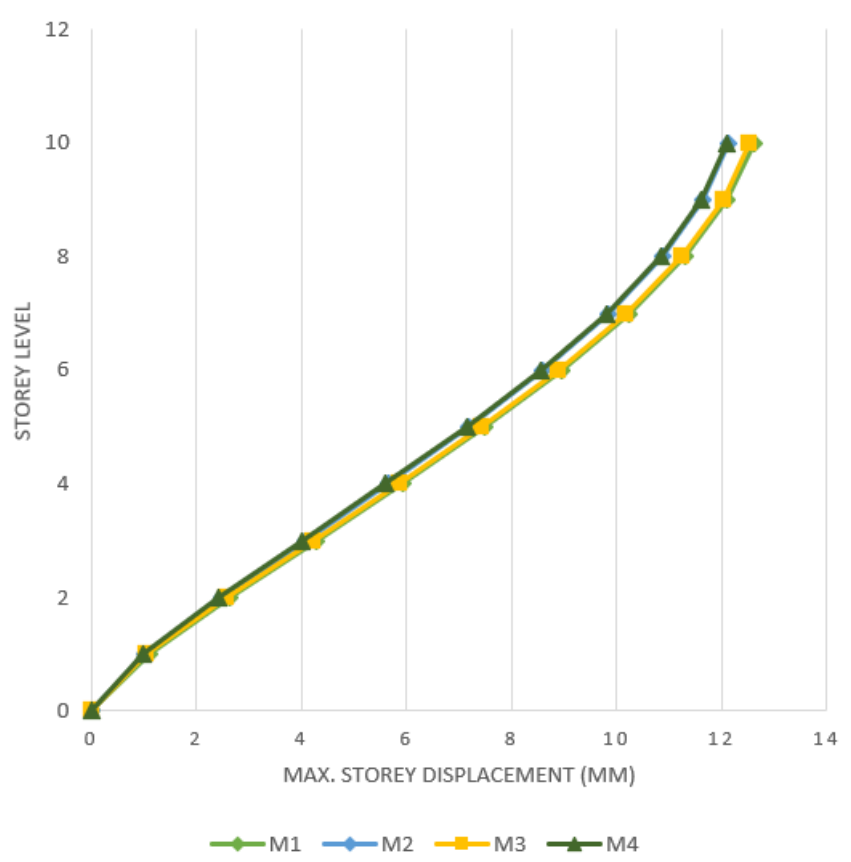

Graph no.1 Max. storey displacement in X-dir. Due to earthquake

4.1.2 Max. storey Displacement due to earthquake in Ydirection

Table no. 2

\begin{tabular}{|l|l|l|l|l|}
\hline Storey & M1 & M2 & M3 & M4 \\
\hline 0 & 0 & 0 & 0 & 0 \\
\hline 1 & 1.269 & 1.165 & 1.246 & 1.147 \\
\hline 2 & 2.825 & 2.667 & 2.796 & 2.645 \\
\hline 3 & 4.433 & 4.235 & 4.4 & 4.214 \\
\hline 4 & 6.019 & 5.785 & 5.982 & 5.765 \\
\hline 5 & 7.542 & 7.271 & 7.499 & 7.251 \\
\hline 6 & 8.959 & 8.651 & 8.909 & 8.629 \\
\hline 7 & 10.222 & 9.877 & 10.163 & 9.851 \\
\hline 8 & 11.276 & 10.896 & 11.206 & 10.863 \\
\hline 9 & 12.063 & 11.652 & 11.982 & 11.612 \\
\hline 10 & 12.549 & 12.12 & 12.459 & 12.074 \\
\hline
\end{tabular}

MAX STOREY DIAPLACEMENT IN YDIRECTION DUE TO EARTHQUAKE

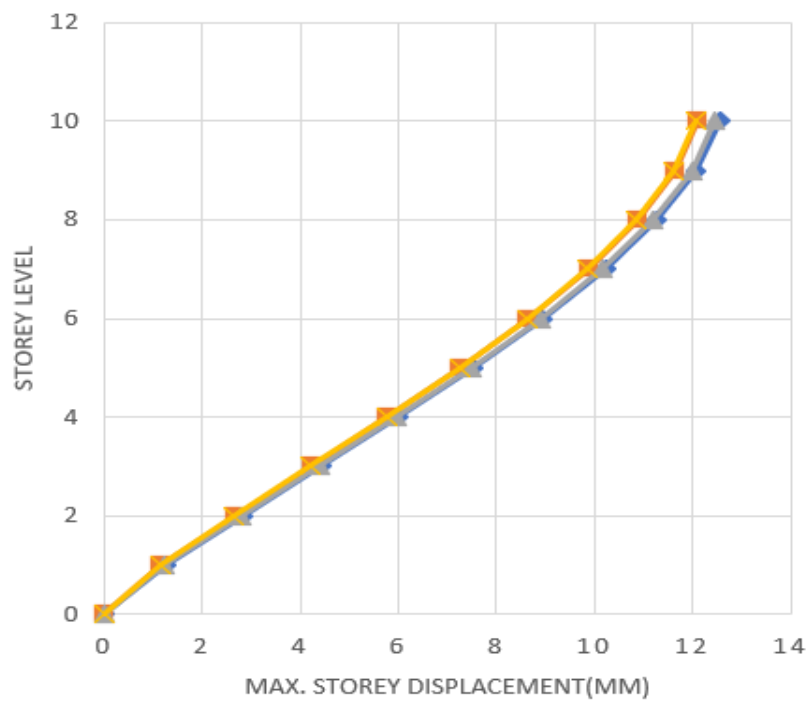

Graph no.2 Max. storey displacement in Y-dir. Due to earthquake 


\subsection{Max. storey drift}

Table no. 3

4.2.1 Max. storey drift in X-direction due to earthquake

\begin{tabular}{|l|l|l|l|l|}
\hline Storey & M1 & M2 & M3 & M4 \\
\hline 0 & 0 & 0 & 0 & 0 \\
\hline 1 & 0.000313 & 0.000287 & 0.000302 & 0.000278 \\
\hline 2 & 0.000514 & 0.000489 & 0.000507 & 0.000484 \\
\hline 3 & 0.00055 & 0.000531 & 0.000548 & 0.00053 \\
\hline 4 & 0.000547 & 0.000531 & 0.000546 & 0.000531 \\
\hline 5 & 0.000525 & 0.000509 & 0.000524 & 0.00051 \\
\hline 6 & 0.000486 & 0.000471 & 0.000485 & 0.000472 \\
\hline 7 & 0.00043 & 0.000417 & 0.000429 & 0.000417 \\
\hline 8 & 0.000356 & 0.000344 & 0.000355 & 0.000344 \\
\hline 9 & 0.000265 & 0.000255 & 0.000264 & 0.000256 \\
\hline 10 & 0.000168 & 0.000164 & 0.000168 & 0.000166 \\
\hline
\end{tabular}

MAX. STOREY DRIFT IN X-DIRECTION DUE TO EARTHQUAKE

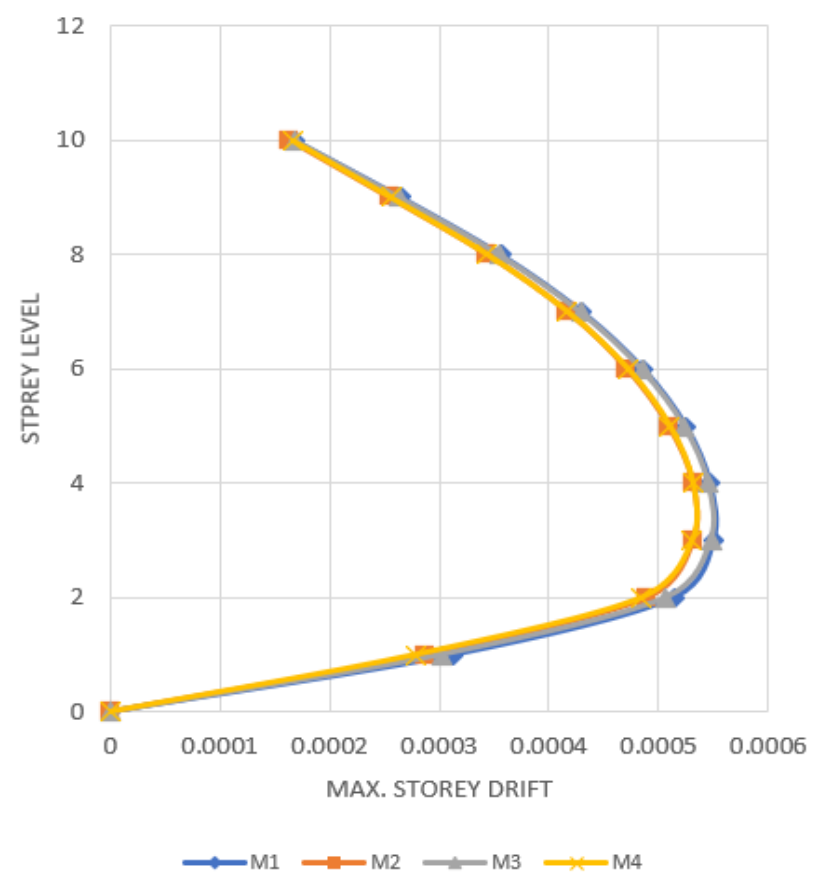

Graph no.3 Max. storey drift in X-dir. Due to earthquake Table no. 4

4.2.2 Max. storey drift in Y-direction due to earthquake

\begin{tabular}{|l|l|l|l|l|}
\hline Storey & M1 & M2 & M3 & M4 \\
\hline 0 & 0 & 0 & 0 & 0 \\
\hline 1 & 0.000363 & 0.000333 & 0.000356 & 0.000328 \\
\hline 2 & 0.00052 & 0.000502 & 0.000518 & 0.0005 \\
\hline 3 & 0.000536 & 0.000523 & 0.000535 & 0.000523 \\
\hline 4 & 0.000529 & 0.000517 & 0.000527 & 0.000517 \\
\hline 5 & 0.000508 & 0.000495 & 0.000506 & 0.000495 \\
\hline 6 & 0.000472 & 0.00046 & 0.00047 & 0.000459 \\
\hline 7 & 0.000421 & 0.000409 & 0.000418 & 0.000407 \\
\hline 8 & 0.000351 & 0.000339 & 0.000348 & 0.000338 \\
\hline 9 & 0.000262 & 0.000252 & 0.000259 & 0.00025 \\
\hline 10 & 0.000162 & 0.000156 & 0.000159 & 0.000154 \\
\hline
\end{tabular}

MAX. STOREY DRIFT IN Y-DIR, DUE TO EARTHQUAKE

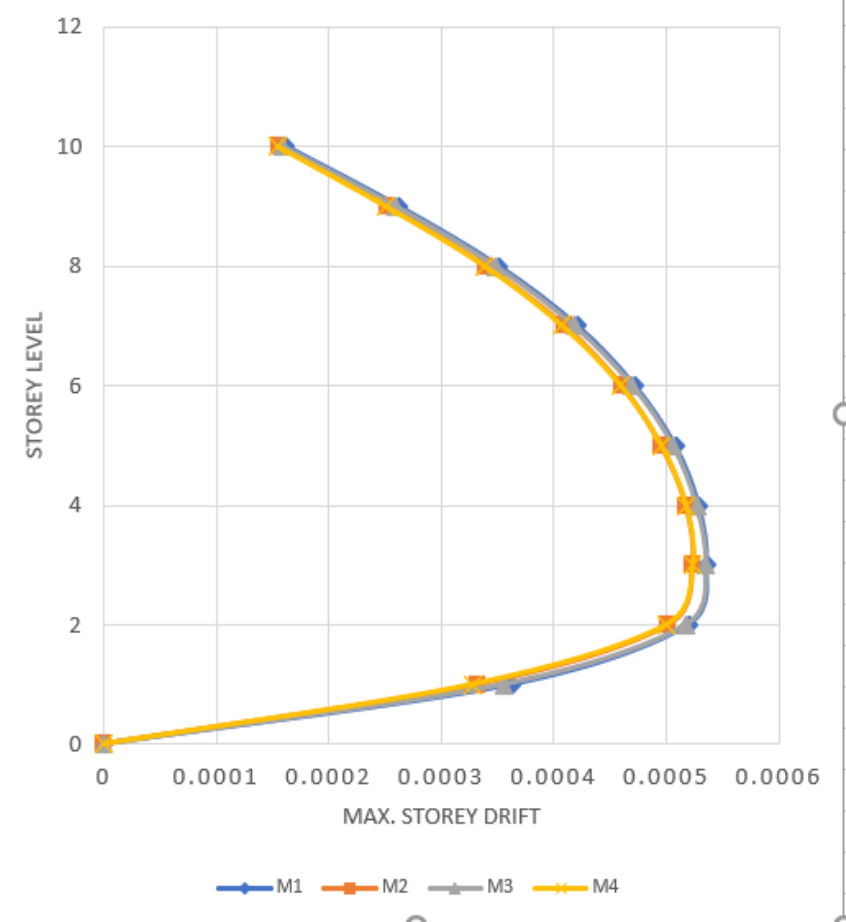

Graph no.4 Max. storey drift in Y-dir. Due to earthquake

\subsection{Base shear}

Table No.5

4.3.1 Storey shear in X-dir. Due to earthquake

\begin{tabular}{|l|l|l|l|l|}
\hline Storey & M1 & M2 & M3 & M4 \\
\hline 1 & 366.1214 & 307.8752 & 374.2663 & 314.9574 \\
\hline 2 & 364.8312 & 306.7787 & 372.9444 & 313.8327 \\
\hline 3 & 360.457 & 303.0763 & 368.4665 & 310.0389 \\
\hline 4 & 351.1134 & 295.1676 & 358.9014 & 301.9348 \\
\hline 5 & 334.9367 & 281.4752 & 342.3413 & 287.9041 \\
\hline 6 & 310.0634 & 260.4218 & 316.8784 & 266.3306 \\
\hline 7 & 274.63 & 230.4301 & 280.605 & 235.5979 \\
\hline 8 & 226.7728 & 189.9225 & 231.6134 & 194.0896 \\
\hline 9 & 164.6285 & 137.3219 & 167.996 & 140.1895 \\
\hline 10 & 86.3333 & 71.0508 & 87.8448 & 72.2812 \\
\hline
\end{tabular}

STOREY SHEARS IN X-DIRECTION DUE TO

EATHQUAKE

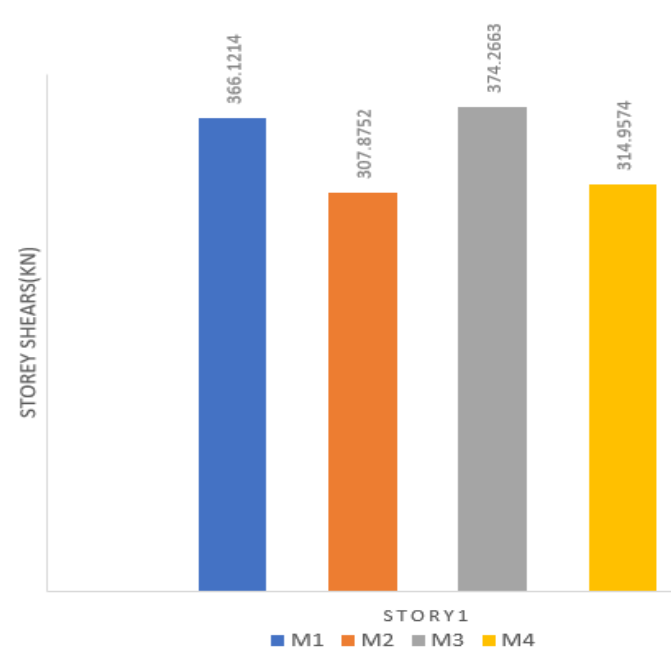

Graph.5 Base shear in X-dir. Due to earthquake 
Table No.6

4.3.1 Storey shear in Y-dir. Due to earthquake

\begin{tabular}{|l|l|l|l|l|}
\hline Storey & M1 & M2 & M3 & M4 \\
\hline 1 & 364.6747 & 305.1256 & 372.0977 & 311.4065 \\
\hline 2 & 363.3897 & 304.0389 & 370.7834 & 310.2945 \\
\hline 3 & 359.0328 & 300.3695 & 366.3315 & 306.5434 \\
\hline 5 & 349.7261 & 292.5315 & 356.8218 & 298.5306 \\
\hline 6 & 333.6133 & 278.9614 & 340.3576 & 284.6582 \\
\hline 7 & 308.8383 & 258.096 & 315.0422 & 263.3279 \\
\hline 8 & 273.5449 & 228.3721 & 278.9791 & 232.9417 \\
\hline 9 & 225.8768 & 188.2264 & 230.2714 & 191.9014 \\
\hline 10 & 163.978 & 136.0955 & 167.0225 & 138.609 \\
\hline
\end{tabular}

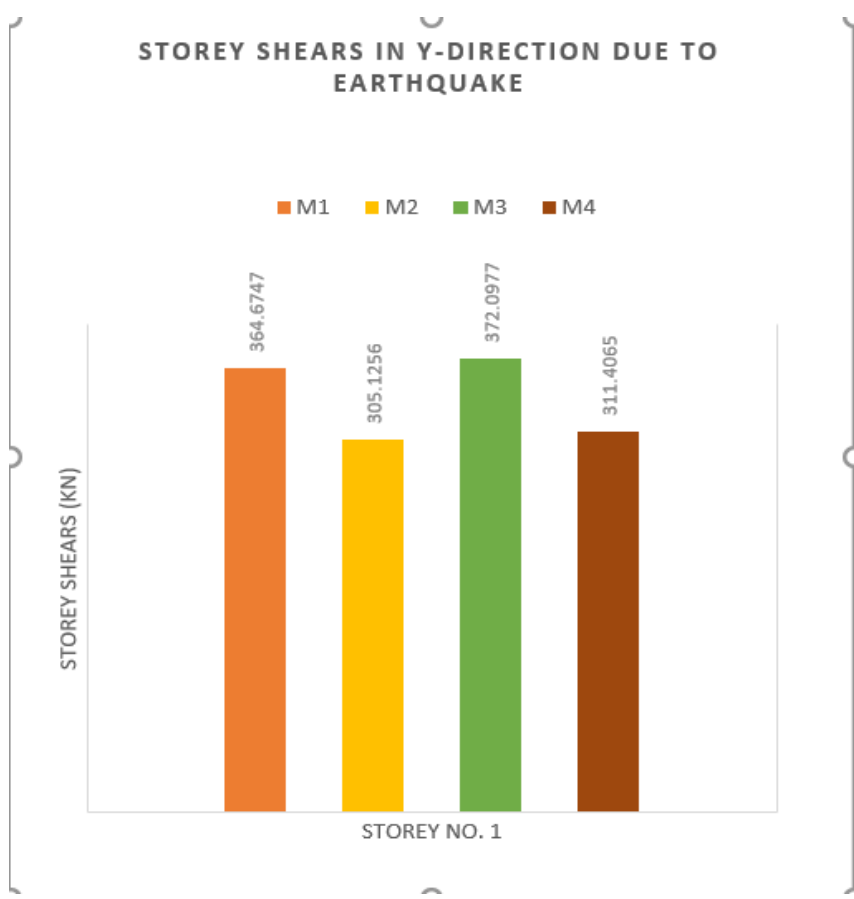

Graph.6 Base shear in Y-dir. Due to earthquake

\section{RESULTS}

Graph no. 1 and 2 shows that, the structure having steel beam with composite column shows more rigidity compared to RCC beam and column framed structure. The storey displacement of Model no. 4 is $5 \%$ less compared to model no. 1. Max. storey displacement differs in $\mathrm{x}$-direction and $\mathrm{y}$-direction due to rectangular geometry and orientation of column.

The permissible limit for displacement is $\mathrm{H} / 500$ where $\mathrm{H}$ is height of building. Total building height is $30.5 \mathrm{~m}$ that means permissible limit for displacement is $61 \mathrm{~mm}$. Permissible limit for storey drift according to IS 1893(part1):2016 is 0.004 times the storey height which is 0.1220 , all models are safe in drift criteria. Max. storey drift for all frame structure is within permissible limit.Storey stiffness differs in X-direction and Y-direction owing orientation column

From chart 5 and 6 it is seen that, Storey shear for steel beam with composite column frame structure has reduced by $15 \%$ compare to that of reinforced concrete structure. Base shear for steel beam with RCC column frame is $16 \%$ less compared to RC framed structure.

\section{CONCLUSIONS}

- By keeping same specification and loading, we designed smaller section composite structure For the same bending moment, axial forces .

- Because of inherent ductility characteristic steel-concrete composite structure under earthquake consideration steel-concrete composite structure performs better

- As compared to RCC frame structure steel beam with RC column frame structure and steel beam with composite column frame structure require less construction time due to quick errction of the steel beam and ease of formwork of concrete

- Including the construction period as a function of total cost in the cost estimation will result in increased economy for the composite structure

- Steel beam with composite column frame structure has less base shear which gives economic foundation design, construction period for steel beam with composite column frame structure is less. Also requirement of construction worker is reduced. Also due to inherent ductility of steel-RC composite structure it performs better in earthquake prone regon

- According to analysis and my study on that I conclude that steel-beam with composite column frame structure is superior over RCC frame structure, steel beam with RC column frame structure, and Composite column frame structure amongs all

\section{ACKNOWLEDGEMENTS}

Praise be to God who gave us life and provided species wisdom. I am infinitely thankful to god who helped me through my whole life. It gives me great pleasure to thank my guide, Prof. J.P.Patankar for their scientific support, accurate and consistent recommendations and their tireless patience during the work of the project. I appreciate their deep knowledge and attention, as well as the encouragement he has given me throughout the entire project. I am grateful to the department of Civil Engineering for giving us the opportunity to carry out this research, which is an integral part of the MTech curriculum at the Government College of Engineering Karad. I sincerely thank all the Applied Mechanics Department professors. I also would like to thank those kindhearted and helpful professors whom I met across my entire course. I would like to thank my classmates and friends for their continued help and encouragement throughout my entire M-Tech studies. Finally, throughout my life, I am extremely grateful to my parents, brothers, sisters and relatives for their love, care, support, encouragement and prayers.

\section{REFERENCES}

[1] Mohamdamir khan "Comparative study of R.C.Chand structural steel -concrete composite frame for linear and non-linear analysis" IRJET Vol:04 Issue: 07 (July 2017)

[2] Prof. Rajendra R. Bhoir, Prof. Vinay kamble, Prof. Darshana ghankute "Analysis and design of composite structure and its comparison with RCC structure" IJARSET vol-5 issue-X,sept2017

[3] Mohammed Imran, Shaik Abdulla, S.M.Hasmi "Comparative analysis of reinforced concrete and composite structures subjected to static and dynamic loads" IJAERD vol-4 issue-7, Aug 2017

[4] S.R.Sutar, P.M.Kulkarni " comparative inelastic analysis of RCC and steel-concrete composite frame"IOSR-JMCE, Volume 13, Issue 4 Ver. IV (Jul-Aug 2016) 
[5] Anamika Tedia, Dr. Savita Maru "Cost analysis and design of steelconcrete composite structure RCC structure" IOSRJMCE,Volume11,Issue1,Ver2 (Jan2014)

[6] Prof. PrakarshSangave, Mr. Nikhil Madur, Mr. Sagar Waghmare, Mr. Rakesh Shete, Mr. Vinayak Mankondi, Mr.Vinayak Gundla, "comparative study of analysis and design of RC and steel structures.'IJSER Vol6 Isuue-2(Feb 2015)

[7] IS:1893 (i)-2002., "Criteria for earthquake resistant design of structures" bis, new delhi.

[8] IS 4326 -1993-: Earthquake resistant design and construction of buildings
[9] IS 456:2000,"Indian standard code of practice for plane and reinforced concrete", bureau of Indian standards, new delhi.

[10] IS 11384:1985, "Code of practices for design of composite structure ", Bureau of Indian Standards, New Delhi, India

11] Euro code 4, "Design of composite steel and concrete structures", European committee for standardization committee European de normalization europaisches committee fur normung 